MARKETING AND BRANDING
RESEARCH $\begin{gathered}\text { INDUSTRIAL } \\ \text { MANAGEMENT } \\ \text { INSTITUTE }\end{gathered}$

\title{
Value Co-Creation Drivers and Components in Dynamic Markets
}

\author{
Daniel Marco-Stefan Kleber*, Tatjana Volkova \\ BA School of Business and Finance, Riga, Latvia
}

\begin{abstract}
Keywords:

Value Co-Creation, Value Innovation,

Dynamic Markets, Superior Customer Responsiveness

Correspondence: daniel.kleber@hs-kl.de

The purpose of this conceptual study is the identification of value co-creation drivers and components and the emphasis of the necessity of value co-creation in today's dynamic business environments. According to Bingham, Furr, and Eisenhardt (2014), these environments are built on dynamic markets which require interaction and experimentation between strategic focus and flexibility. "Outside the box thinking" or "thinking with no boxes" is vitally important for the value creation process in global markets (Lewis, Andriopoulos, \& Smith, 2014). In this article, the role of customers in value co-creation processes and systems will be highlighted. The co-creation of value with customers' involvement shapes and redefines existing markets and helps to create new market spaces based on the customers' needs and demands which result in boundless opportunities in a globalized world of ever-changing markets (Bettencourt, Lusch, \& Vargo, 2014). This qualitative study is based on content analysis of distinctive value co-creation management studies streams in scientific literature from related research concepts such as consumer service management and innovation management research for ensuring superior customer responsiveness in dynamic markets by embedding the service-dominant logic (SDL) and the job-to-be-done thinking logic (JTBD). The article gives an overview over perspectives, conceptualizations, and application approaches of value co-creation with customers. In addition, multidimensional approaches of value co-creation are discussed and spheres of value co-creation are formulated. At last, critical drivers for delivering value co-creation are highlighted.
\end{abstract}

(C)AIMI Journals

According to Leclercq, Hammedi, and Poncin (2016), in increasingly complex competitive business environments, the opportunities of value creation and value co-creation with customers becomes a highly challenging but critical task for companies as their future 
success depends on their ability to co-create customer value. Therefore, research of the relationship between today's dynamic markets and mutual value co-creation with customers is imperative to meet the changes and challenges and to lead the company to sustainability and to future success (Leclercq et al., 2016). Thus, the application and development of tools for value co-creation based on new thinking logics to ensure increased value and superior customer responsiveness, as well as strategic advantages for the company is on the management research agenda.

The article identifies three different research streams of value creation and delimitates value co-creation from related concepts such as open innovation, co-production, prosumption, and co-destruction. Moreover, critical components of value co-creation which are value, actors and an engagement platform are pointed out. Additionally, the article highlights different types of value which can be co-created by actors and identifies drivers and components of value co-creation. It deals with three spheres of value co-creation and demonstrates how service oriented approaches such as the service dominant logic (SDL) or the job-to-be-done logic (JTBD) can positively influence the process of value co-creation.

Value co-creation is a mutually beneficial managerial response to fast changing conditions while achieving strategic advantages for both the company and the customer. The authors suggest that value co-creation has a complex management nature: It is a tool, a collaboration process, and a system. Value co-creation as a management tool could be used to ensure superior responsiveness to customers' needs and demands, thus, adjusting value propositions to the dynamic markets of the $21^{\text {st }}$ century. Value creation as a collaboration process of both customers and companies aim at creating new product or service attributes. Value cocreation as a system can be interpreted as a configuration of elements which is connected to other systems by value propositions, aiming at an integration of mutually beneficial resources.

As the importance of value delivered to customers in increasing competitive landscapes grows, creative customer oriented insights help to create new value attributes, thus, ensuring superior customer responsiveness and satisfaction. The importance of value co-creation with customers to develop valuable product or service features and also to design, for example, aftersales services which improve the overall user experience is increasing. As a consequence, strategic and competitive advantages may arise. The purpose of this conceptual study is the identification of value co-creation drivers and components and the emphasis of the necessity of value co-creation in today's dynamic business environments.

\section{Value Co-Creation Characteristics}

According to Galvagno and Dalli (2014) and Leclercq et al. (2016), three different research streams, namely consumer, service management, and innovation management research concerning value co-creation can be observed. Across these streams, different perspectives on value co-creation can be identified. While the consumer research stream mainly deals with motives on participants to get involved in value co-creation processes, the service management stream focuses on understanding the process underlying value co-creation actions (Leclercq et al., 2016). The innovation management stream, on which the authors will focus in this article, concentrates on settings which enable actors to co-create value 
reciprocally. In addition, the authors suggest that the customer relationship management perspective should be taken into consideration.

Caru and Cova (2003), Woodall (2003), and Sánchez-Fernández and Iniesta-Bonilla (2007) regard value as one of the most elusive and ill-defined concepts in management as a number of different conceptualizations exist. However, on a rather general level, one can argue that value creation incorporates a process which increases the customers' well-being (Grönroos, 2008; Vargo \& Lusch, 2008; Nordin \& Kowalkowski, 2010). According to the authors, value has to be seen from the customer's and from the company's perspective. The value to a customer is the benefits of the product or service valued by the customer. The value could be added or reduced by the experience received during the sales, usage, and aftersales as it leads to emotional, financial and physical satisfaction or dissatisfaction. The value to a company is the profit generated as a result of the company's activities. It could be created in cooperation with wider stakeholders such as suppliers, competitors, and other organizations which have interests in the company's activities. As the article focuses on value co-creation with customers, this aspect of creating company value with wider stakeholders is not further discussed. However, focusing on value co-creation with customers, one can say that this concept can lead to added value for both the customers and companies.

The origin of the concept of value co-creation comes from Vargo and Lusch (2004, 2008). According to them, all customers are considered to be value co-creators. This view was redefined by Grönroos (2012) who mentions a further detailed approach than Vargo and Lusch. Grönroos (2012) describes activities of customers as economic value creationactors whereas value co-creation requires two or more economic factors such as customers and providers. Grönroos' (2012) conceptualization of value co-creation is also in line with Ballantyne and Varey (2006) and Prahalad and Ramaswamy (2004a, p. 5) who even claim that "the use of interaction as a basis for co-creation is at the crux of our emerging reality." Prahalad and Ramaswamy (2004a) further argue that a co-creation of value can also be achieved by interaction among other stakeholders such as business partners, public organizations, competitors or suppliers. According to them, value co-creation is a joint initiative in which providers and beneficiaries co-create value. The authors agree that the role of wider beneficiaries such as business partners, public organizations, suppliers, and other external and internal stakeholders in value co- creation has to be further investigated, thus, this can be interpreted as a focus for additional management research.

Holbrook (2006) strongly emphasizes the customer perspective, what is in line with Grönroos (2012), but he sees value as an "interactive, relativistic preference experience". From the authors' point of view, an overemphasizing role of one or another economic actor in value co-creation can limit its potential as the roots for increasing value for both customers and companies can come from different sources and in parallel and, thus, implying different approaches for value co-creation.

Leclercq et al. (2016) conceptualize value co-creation as a process in which actors jointly create value by exchanging resources. They define value co-creation as a joint process during which value is reciprocally created for each actor. These actors engage in the process by interacting and exchanging their resources with one another.

Truong, Simmons, \& Palmer (2012) also supports this definition. They state that during the value co-creation process, value is reciprocally created as each actor performs both roles in 
return. From the authors' point of view, actors who are involved in value co-creation exchange resources and experiences.

As, among researchers, there is a lack of a clear definition of value and value co-creation or its dimensions, the concept of value co-creation is rather complex as there is only little agreement on a commonly used conceptualization of value co-creation. As different groups of researchers make various paradigmatic assumptions regarding value and value cocreation, it is difficult to understand what practitioners or researchers refer to when dealing with value co-creation (Neghina, Caniëls, \& Bloemer, 2015).

From the authors' point of view, value should not be solely created for customers by the provider of goods and other services. It must be co-created based on interaction by and for both beneficiaries. One can, therefore, say that value could be jointly created through resource exchange by the provider and the customer as an ongoing value co-creation process. It can be regarded as a process leading to an outcome of interaction between subjects as well. The authors further argue that value co-creation supports the process of satisfying customers' needs, solving customers' problems, and adding value to companies which is also in line with Grönroos and Voima (2013).

Additionally, the authors identified a strong correlation between overall product-fit and customer satisfaction, also leading to superior customer responsiveness and their loyalty. Therefore, the importance of a joint value co-creation process with customers becomes vitally important in today's dynamic markets. The authors further argue that superior customer responsiveness can be regarded as a result of adjusting value propositions to the changing needs and demands of customers. This perspective is also in line with Amit and Zott (2010) who see a great importance in solving customer problems while simultaneously satisfying customer needs with value propositions. Kotler, Armstrong, Harris, and Piercy (2013) argue that value propositions describe how products or services differentiate from others while delivering increased customer value. Hoveskog, Halila, and Danilovic (2015) point out the need of an ongoing reevaluation and readjustment of value propositions in terms of usefulness, novelty, and feasibility.

The authors' perspective on value propositions is in line with Amit and Zott (2010), Hoveskog et al. (2015), and Kotler et al. (2013) as in today's fast changing and dynamic markets, they see a need of steadily adjusting value propositions which are still valuable to customers in today's business environments. Moreover, the authors argue that value propositions can also be interpreted as the result of customers' involvement in value cocreation processes as a successful involvement forms the basis of powerful value propositions which are still valuable from the customers' point of view.

\section{Conceptual delimitation and differentiation of Value Co-Creation and its closest concepts}

After having clarified the authors' perspective on value co-creation, it needs to be differentiated from related concepts such as value co-destruction, co-production, prosumption, and open innovation.

Ple and Caceres (2010) consider value co-destruction as a situation leading to a decline of value for at least one of the involved actors. Although, value co-destruction also incorporates 
interaction between actors and resource integration of both parties (like value co-creation), value is not reciprocally created.

Vargo and Lusch (2004) describe eco-production as the participation of actors in the execution of activities that occur in at least one of the stages preceding the consumption of the offering (Vargo \& Lusch, 2004; Vargo, 2008). By the co-production of an offering, actors can co-create, but also co-destroy value. Co-production can be distinguished from value co-creation as it is limited to the offering creation stage while value co-creation incorporates a wider scope as it also includes interactions during the consumption of the offering (Leclercq et al., 2016). Prosumption can be defined as an involvement of consumers in product and/or service creation which will eventually be consumed by them (Xie, Bagozzi, \& Troye, 2008). Prosumption relates foremost to managerial practices such as service provision or customization (Leclercq et al., 2016). In contrast, open innovation can be regarded as companies' abilities to externally or internally perform management tasks (Chesbrough, 2006; and Lichtenthaler, 2009). Open innovation strongly focuses on innovational purposes while value co-creation includes a rather broad range of activity (Enkel, Gassmann, \& Chesbrough, 2009). The authors consider an open innovation as a management tool and as a process which could be used to create value propositions or adding value to both customers and companies.

\section{Components of Value Co-Creation}

According to the literature, the concept of value co-creation consists of several components which forma management process, a management tool, and also a management system of value co-creation. There are three critical value co-creation components, namely value, actors, and the engagement platform that are mentioned by Saarijärvi, Kannan, and Kuusela (2013) and supported by Mahr, Lievens, and Blazevic (2014) and Leclercq et al. (2016). The following section describes how the authors interpret the above-mentioned components as the description of these elements varies across different researchers.

\section{Value as a component of Value Co-Creation}

A focus on joint value creation distinguishes the concept of value co-creation from others. The conceptualization of value helps to understand how value is co-created and who cocreates value. Four types of value can be identified from prior literature review based on a thorough content analysis (Grönroos, 2008; Sheth \& Uslay, 2007).

Value-in-exchange is interpreted by Zeithaml (1988) as the beneficiaries' perception of the value achieved by exchanging resources such as monetary, social or physical elements. Nambisan and Baron (2007) and Roberts, Hughes, and Kertbo (2014) interpret value-inexchange as the recognition of participants' motives to engage their resources in a process of value co-creation. As a consequence, it can be interpreted that the aim of value co-creation is the optimization of the tradeoff beneficiaries for both actors who are involved in the process (Sheth \& Uslay, 2007).

Value-in-use is described by Grönroos (2008) as the extent to which the usage of a product or service enhances the users' perceived value. Following Vargo and Lusch (2008) and the service dominant logic (SDL), beneficiaries see themselves as value co-creators as the consumers of a product or service are the ones who assign value and evaluate the 
products or the providers' propositions (Vargo \& Lusch, 2008). One can, therefore, say that providers are integrated into the beneficiaries' consumption process to enable them to create and design the best value proposition, which is tailored to the needs and demands of consumers for the overall maximization of beneficiaries' value (Vargo \& Lusch, 2004; Leclercq et al., 2016).

Vargo and Lusch (2008) interpret value-in-context as the beneficiaries' opportunity of experiencing value without making direct use of the offer. One can describe value-in-context as a concept in which value is indirectly co-created within an, for example, social context (Vallaster \& von Wallpach, 2013).

Fourthly, a broader conceptualization of value can be described by Holbrook's (2006) experiential approach which includes a more detailed view on different dimensions of value and which also considers the indirect way of value co-creation.

From the authors' point of view, all of the above-mentioned dimensions of value describe how value can be co-created by beneficiaries. In addition, one can state that value is cocreated by interactions of the participating actors. Therefore, the authors regard the concepts of value-in-use and value-in-exchange as best suited for the value co-creation system due to the fact of direct value co-creation actions among actors. One can, therefore, say that these concepts focus on direct and mutual value co-creation.

\section{Actors as a component of Value Co-Creation}

Value co-creation incorporates several different stakeholders (depending on the definition) such as customers, partners, competitors, firms or public organizations (Prahalad \& Ramaswamy, 2004b; Vargo \& Lusch, 2011). According to Leclercq et al. (2016), there are three possible contributions to value co-creation processes which can be made by different actors. Firstly, actors can develop a dialogue and interact with providers while investing their resources. Secondly, actors have the possibility to interact with elements that are not included in the actual process of value co-creation. Thirdly, an action oriented distribution of resources during the value co-creation process can help to accelerate interaction to boost value co-creation (Leclercq et al., 2016).

The authors see providers and customers (as well as partners, suppliers, and other stakeholders) as main actors in a process of value co-creation in which value is created reciprocally. The above described activities, which foster the process of value co-creation, are regarded as accelerators of value co-creation.

\section{An Engagement Platform as a component of Value Co-Creation}

An engagement platform can be described as a place in which actors interact and exchange resources to create mutual value (Ramaswamy \& Ozcan, 2014). Engagement platforms need to be created to facilitate dialogue and to enable unlimited access to information and transparency. They can either be online or offline. Shared benefits and risks between all actors for co-creation processes is an outcome of the usage of engagement platforms (Ramaswamy \& Gouillart, 2010).

As several actors can take part in value co-creation processes, the interactional structure of engagement platforms can be one-to-one (Grönroos \& Voima, 2013; Vargo \& Lusch, 2011), one-to-many (Füller, Hutter, Faullant, 2011; Sawhney, Verona, \& Prandelli, 2005), 
many-to-many (Sawhney et al., 2005) or networked (Edvardsson, Tronvoll, \& Gruber, 2011; Jaakkola \& Hakanen, 2013; Nätti, Pekkarinen, Hartikka, \& Holappa, 2014).

Aiming at new product or service creation by the co-creation of value, the authors regard the usage of customers' ideas to develop new offers which are tailored to the recipients' needs and wants as obligatory. This approach is in line with the innovation research stream which focuses mainly on a firm's interaction with multiple actors (one-to-many) or between various firms and actors (many-to-many). The authors see the engagement platform as a tool which allows actors to exchange resources as well as experience and to interact with one another. However, a lack of information or transparency incorporates a risk of misusage of resources which could potentially lead to value co-destruction (Leclercq et al., 2016; Ple \& Caceres, 2010).

\section{Spheres of Value Co-Creation}

This section elaborates on the above presented content and introduces three value creation spheres which focus on the customers' and the service providers' role during the process of value co-creation (Grönroos \& Voima, 2013). As the service providers as well as the customers are considered to be value creators, one needs to clarify in which sphere value cocreation takes place. Grönroos' (2008) concept of value-in-use can be regarded as the extent to which a customer feels better off as an user-driven view on customer solutions is integrated. The concept describes that actions taken by customers and how they affect the value being created. As a consequence, one can interpret that they are in charge of value creation as value is not created by the provider solely. This critical role of the customer was also identified by SDL researchers. However, one can also interpret that the provider oversees delivering value creation. Value co-creation with customers is possible in a joint sphere of customer and product or service provider (Figure 1). Figure 1 presents the value creation spheres. In this joint sphere, the value provider and the customer mutually influence each other and will, therefore, lead to value co-creation (Grönroos \& Voima, 2013).

In the provider sphere, potential value is created which is later turned into real value (inuse) by customers. Providers' activities in this sphere aim at facilitating customer value creation. One can, therefore, interpret a firm's role in the provider sphere as value facilitator. From a provider's/firm's perspective, external stakeholders such as, for example, customers are invited to contribute to the development of ideas and solutions (Grönroos, 2011; Hoyer et al., 2010). 


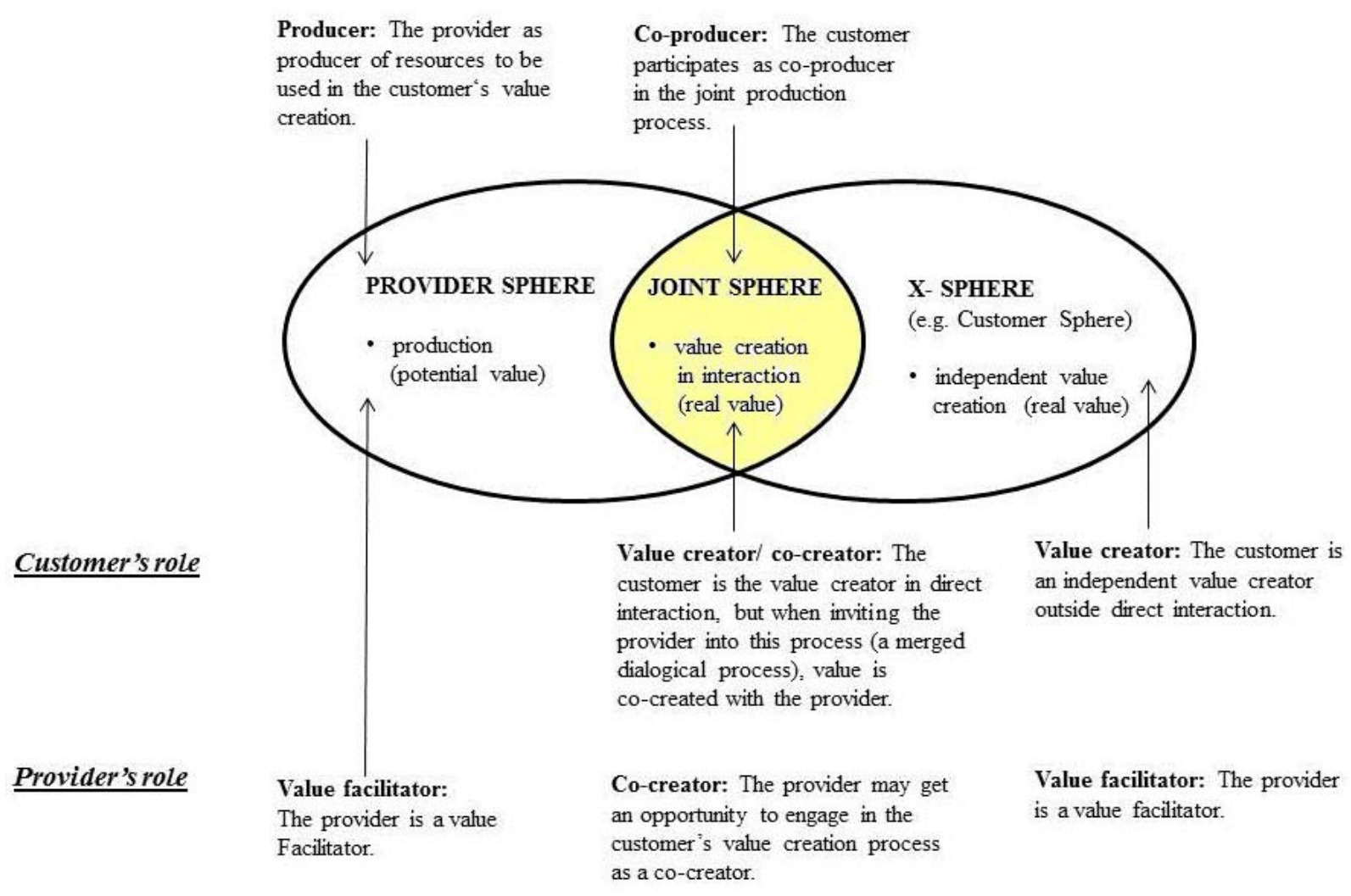

Figure 1. Value creation spheres

The customer sphere is the place where the customers independently combine different resources and experiences to open up the opportunity for value creation. One can see the customer sphere as an experiential sphere in which value-in-use is created through customers' combination of experiences with resources and processes. From this perspective, actors' engagement towards value creation has positive impacts on, for example, customer loyalty, satisfaction or their relationship with the firm (Atakan, Bagozzi, \& Yoon, 2014; Gallan, Jarvis, Brown, \& Bitner, 2013; Grönroos \& Voima, 2013).

In the joint sphere, interaction leads to value creation supported by a dialogical process. The customer is in direct charge of value creation in the joint sphere. However, the provider has the opportunity to influence the customers' value co-creation process by direct interaction. According to Grönroos (2011), direct interaction is essential for value co-creation. Without direct interaction, value co-creation cannot take place. These interactions can also be interpreted as a platform for joint value co-creation (Grönroos \& Voima, 2013). Co-created contents generally outperform the contents which are professionally created by the provider, on key market performance metrics (Black, Vincent, Skinner, 2014; Santos-Vijande, González-Mieres, \& Lopez-Sanchez, 2013). From an innovational point of view, providers often tend to focus on the information which they consider as relevant and miss opportunities to develop innovations which correspond to customers' needs and demands. Through enabling an open dialogue, firms can understand the customers' point of view and create new products and service offerings according to the preferences of customers while at the same time reducing the risk of product failure. Moreover, providers develop and strengthen the 
relational bonds with their customers during value co-creation processes (Bogers, Afuah, \& Bastian, 2010; Nambisan \& Baron, 2007; Roser, DeFilippi, \& Samson, 2013; Ballantyne \& Varey, 2006).

From the authors' point of view, the joint sphere is the place in which the customers take responsibility of value creation by applying a dialogical approach of direct interactions. During this process, the provider has the possibility to influence the customers' value creation process as value co-creator. In this sphere, mutual value is created. This perspective is in line with Grönroos and Voima's (2013) view on the process of value co-creation.

\section{Service oriented Logics for Achieving Value Co-Creation}

The service oriented logic (SDL) shifts the focus from the firm's creation and the distribution of outputs to a co-creation of value with customers (Vargo \& Lusch, 2004). While the SDL can be seen as an overarching and outreaching construct for understanding the creation of value, the job-to-be-done logic (JTBD) makes theory actionable and can be regarded as both strategic and practical (Bettencourt et al., 2014).

The JTBD view shifts the firms' innovation focus from concentrating what is being produced by companies to the question "what enables customers to get their jobs done?" (Ulwick, 2002). According to Christensen and Raynor (2003), jobs of customers became a key success factor for designing products and services, and sustainability and business model innovation. The combination of customers' jobs and service orientation enables companies to envision future opportunities and supports the critical role of customers as contributors to value creation. Figure 2, based on Bettencourt et al. (2014), shows the traditional perspective of value creation and the above described service oriented approach using the JTBD logic for value creation.

Traditional lens on value creation

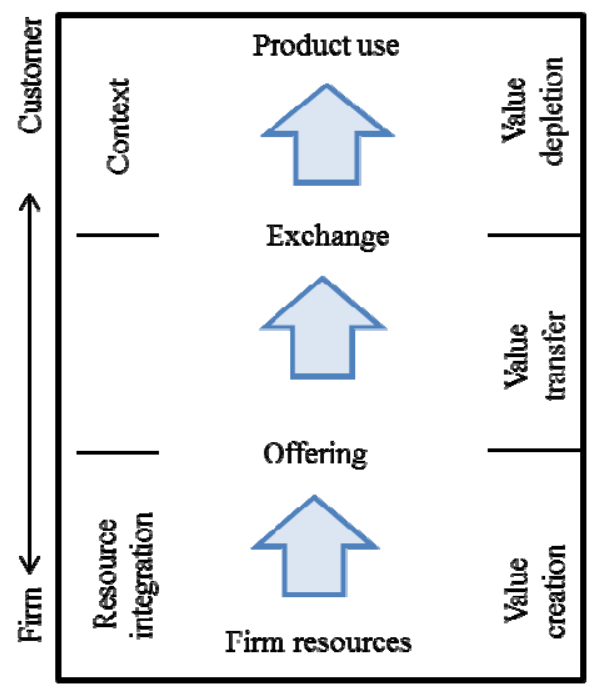

LEADS TO ...
$\Lambda$ service lens on value creation

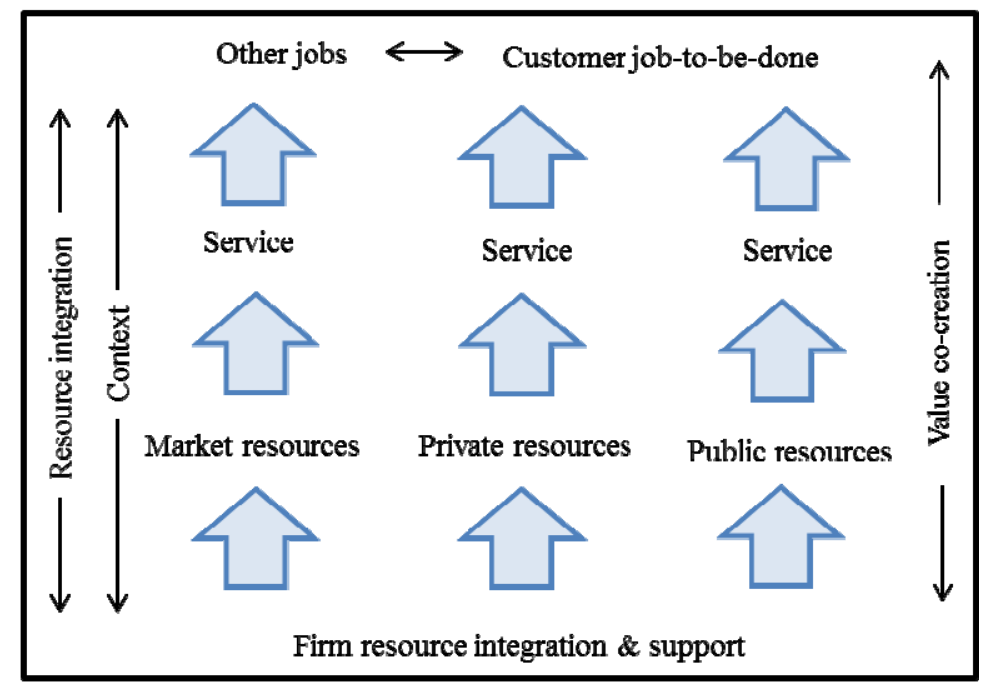

LEADS TO ...
Bounded questions focused on improving how things are done today
Unbounded questions focused on improving how things should be or might be

Figure 2. Traditional and service approach for value creation 
Figure 2 depicts the traditional perspective on value creation in which value can be regarded as an element that is created by firms, transferred to and then depleted by customers. According to the JTBD logic, companies do not necessarily offer products to customers. It rather describes the process of exchange between provider and customer during which value is co-created (Bettencourt et al., 2014).

The authors regard the JTBD as a truly customer-centric logic which applies value cocreation to overcome traditional boundaries and perspectives in business to create strategic advantages. There are boundless market opportunities and benefits as value co-creation opens new possibilities as the perspective on customers' value is not being limited to the status of how things are currently done. Instead, customers will be given the chance to co-design and co-develop products and services that fit to their own needs and demands, leading to an increased value experience in the future. Thus, customers can be regarded as co-creators of value.

A real-life example of the JTBD logic is Amazon's “Kindle Fire". In 2004, Amazon began researching and developing ideas how to realize its vision to make it easier than ever and to simplify the customers' process of enjoying books. This customer- and service-centric vision led to the development and launch of the "Kindle E-Reader" in 2007 which was sold out in 5.5 hours after its release. This could be interpreted as a result of a continuous integration of customers' wishes and demands in the creation stage of the new product. Kindle continued with an ongoing development and upgrade of its E-Reader according to the needs and wants of customers. In 2011, the first Kindle Fire, a tablet which integrates customer access to more than 18 million movies, books, magazines, TV shows, games and apps was released as a product of continuous value co-creation through an integration of customers. The Kindle Fire is an example of how service and customer jobs can complete one another (Bettencourt et al., 2014).

As the example shows, a firm which applies the JTBD logic removes mental constraints of current offerings by clearly focusing on the redefinition of knowledge and skills which supports customers in getting their jobs done. As a consequence, it can be said that a focus of strategy is identifying valuable, sustainable, and unique ways of connecting a company's knowledge and skills with individuals who have jobs which need to be done and which will benefit from the above-mentioned resources (Hamel \& Prahalad, 1994).

In addition, Chandler and Vargo (2011) do not see value as something that things or humans possess. They rather interpret the customers as potential enablers of value in a process of value co-creation. One can also say that value does not come during acquisition. It is rather realized during job-accomplishment (value-in-use) which shifts the traditional perspective of a customer as a passive recipient to an active participant in value co-creation; as from this point of view, companies cannot unilaterally create value (Grönroos, 2000; Vargo\& Lusch, 2004).

At that point, one also has to raise the question that how customers judge and define value. From Bettencourt\& Ulwick's (2008) and Bettencourt et al.'s (2014) point of view, value is determined by the customer and depends on how well, convenient, reliable, effective, and affordable the customers' jobs can be done. These success factors are not tied to a particular offering; instead, they can be seen as a basis for creative thinking about new ways of enabling value (Bettencourt et al., 2014). 
However, another critical factor which needs to be mentioned is that once it is understood that value is only created through co-creation processes with customers, the choice of customers becomes an important factor for the success of the entire organization (Bettencourt et al., 2014).

Looking at the construction company EMCOR, the company managed to successfully implement the JTBD logic. While competing construction firms are production oriented and see their core business in the construction and design of buildings, EMCOR will construct and operate them according to the customers' demands. EMCOR also provides services such as maintenance, repairs or information technology issues (Bettencourt et al., 2014).

According to the authors' point of view, EMCOR can therefore be rather regarded as a value enabler than a value distributor. The customer is not a pure target for value delivery. Instead, customers can be seen as partners who contribute to the value creation process. It can be stated that EMCOR has created a strategic advantage by helping its customers to get their jobs done (Bettencourt et al., 2014).

The above-mentioned example highlights the shift from a traditional business perspective to the service oriented JTBD logic which includes elements such as corporate strategy, innovation potential, value creation, market segmentation, value proposition, customer support, and market research. Table 1 represents the traditional business perspective versus the JTBD logic.

Table 1

The Traditional Business Perspective vs. the JTBD Logic

\begin{tabular}{|c|c|c|}
\hline Topic/Role & Traditional Business Perspective & JTBD \\
\hline Corporate Strategy & $\begin{array}{l}\text { Create unique and sustainable value by differentiating } \\
\text { goods and services. }\end{array}$ & $\begin{array}{l}\text { Find unique, valuable, and sustainable ways of } \\
\text { linking together a firm's knowledge and skills with } \\
\text { customers who have jobs that will benefit from them. }\end{array}$ \\
\hline Innovation Potential & $\begin{array}{l}\text { Create improved goods and services based on customer } \\
\text { needs. }\end{array}$ & $\begin{array}{l}\text { Help customers get job done successfully via } \\
\text { services provided by the firm. }\end{array}$ \\
\hline Value Creation & $\begin{array}{l}\text { Embed value in goods and services that are distributed } \\
\text { to customers. }\end{array}$ & $\begin{array}{l}\text { Enable value to be created in collaboration with } \\
\text { customers via service flows to get a job done. }\end{array}$ \\
\hline Market Segmentation & $\begin{array}{l}\text { Target customers who are willing and able to purchase } \\
\text { a particular solution to satisfy their needs. }\end{array}$ & $\begin{array}{l}\text { Choose customers who are willing and able to play a } \\
\text { particular service role in satisfying their value } \\
\text { criteria in getting a job done. }\end{array}$ \\
\hline Value Propositions & $\begin{array}{l}\text { Make promises about the value embedded in a solution } \\
\text { based on its form and features. }\end{array}$ & $\begin{array}{l}\text { Make promises that acknowledge customers' service } \\
\text { co-creation role based on how customers define } \\
\text { success in getting a job done. }\end{array}$ \\
\hline Customer Support & $\begin{array}{l}\text { Help the customer to resolve problems with the firm's } \\
\text { goods and services. }\end{array}$ & $\begin{array}{l}\text { Help the customer to be more effective in their value } \\
\text { co-creation role in getting a job done. }\end{array}$ \\
\hline Market Research & $\begin{array}{l}\text { Monitor the customer environment and product usage to } \\
\text { improve the customer experience with the firm's goods } \\
\text { and services. }\end{array}$ & $\begin{array}{l}\text { Connect to the complete customer experience in } \\
\text { getting a job done in particular contexts in order to } \\
\text { configure resources to support value co-creation. }\end{array}$ \\
\hline
\end{tabular}

Source: Authors' modified illustration based on Bettencourt et al. (2014)

Table 1 visualizes the redefined role of customers and providers according to the service oriented JTBD logic. Strategic advantages can be created by considering how skills and knowledge can be applied in the process of value co-creation resourcefully in order to deliver the desired value. Through this approach, the co-creation of value can redefine existing markets or even helps to create new markets (Bettencourt et al., 2014).

The authors regard the JTBD logic as a set of processes which co-create value with customers by identifying the customers' needs and demands and co-creating solutions, which fit these needs and wants to achieve increased value. Connecting the resources of individuals 
and businesses gives the opportunity of co-creating value in an ever-changing market and even serves as opening element for entirely new markets.

\section{Drivers of Value Co-Creation}

Neghina et al. (2015) describe three antecedents of value co-creation including communicating, relating, and knowing. Based on these antecedents, value co-creation drivers can be derived. On the basis of a critical literature review, a positive correlation between the drivers and value co-creation activities could be observed.

According to Neghina et al. (2015), the frequency of bidirectional communication positively influences value co-creation. In addition, they regard interpersonal trust between employees and customers as a driver which positively influences value co-creation. Moreover, they identify commitment between customers and employees as a value cocreation driver. Gwinner, Bitner, Brown, and Kumar (2005) further see information sharing as another driver of value co-creation and Sebanz, Bekkering, and Knoblich (2006) regard feedback as another element which positively influences value co-creation.

Additionally, Bettencourt et al. (2014) believe that the education of staff to enable them to systematically understand where and when customers struggle with the product or service is critical and can, therefore, be interpreted as another driver of value co-creation. A new mindset needs to be established among those who oversee guiding the value co-creation process which includes elements such as product development, business model development, marketing or strategy. Furthermore, the concept of value co-creation has to be embedded in already existing processes. A successful integration is a critical success factor of value cocreation as this kind of changes can move individuals in a positive (or negative) direction while linking them to familiar routines at the same time (Bettencourt et al., 2014).

\section{Conclusion}

The article aimed at providing an overview over perspectives, conceptualizations and application approaches of value co-creation for ensuring superior customer responsiveness. It deals with existing value co-creation spheres, components of value co-creation, and underlying logics for delivering value co-creation such as the SDL or JTBD logic which are derived from existing research literature. A thorough scientific management literature review was conducted.

Firstly, the concept of value co-creation was explained and the perspectives of different research contributors were highlighted. Secondly, a differentiation and delimitation of related concepts of value creation was performed and the components of value co-creation were pointed out. In addition, spheres of value co-creation were formulated.

Service focused logics such as the SDL and the JTBD were embedded in the process of value co-creation with customers and a shift from the traditional to the customer oriented approach for ensuring value co-creation in today's dynamic markets was highlighted. Furthermore, critical drivers of value co-creation were identified from prior literature.

As highlighted by the authors earlier, value propositions aim to provide specific advantages and benefits which intend to solve customers' problems. Therefore, one can say that value propositions are primarily about the needs and demands of the end-customers and their experience (Barnes, Blake, \& Pinder, 2009). 
The authors regard value co-creation as a tool, as a collaboration process, and as a system for jointly creating new product or service attributes or delivering new products or services which are performed together with the customers. Based on a systematic approach, the service oriented JTBD logic can be applied to support the process of value co-creation.

In addition, the authors suggest that value co-creation can be interpreted as a prior step to value innovation, which itself can be considered as a key success factor for ensuring superior customer responsiveness. Moreover, the article summarizes the key driving forces of value co-creation to ensure strategic advantages of a company.

To conclude, the article points out possibilities of co-creating value to ensure that customers' needs and demands are met to achieve and adjust value propositions which are even valuable to customers in today's ever-changing markets. The reciprocal value creation which aims at achieving benefits for customers as well as strategic advantages for companies can be interpreted as mutually beneficial for involved parties and as a basis for value innovation.

\section{References}

Amit, R., \& Zott, C. (2010). Business model design: An activity system perspective. Long Range Planning, 43(2), 1-11.

Atakan, S. S., Bagozzi, R. P., \& Yoon, C. (2014). Consumer participation in the design and realization stages of production: How self-production shapes consumer evaluations and relationships to products. International Journal of Research in Marketing, 31(4), 395-408

Ballantyne, D., \& Varey, R. J. (2006). Creating value-in-use through marketing interaction: The exchange logic of relating, communicating and knowing. Marketing Theory, 6(3), 335-348.

Barnes, C., Blake, H., \& Pinder, D. (2009). Creating and delivering your value proposition: Managing customer experience for profit. London: Kogan Page.

Bettencourt, L. A., Lusch R. F., \& Vargo, S. L. (2014). A Service lens on value creation: Marketing's role in achieving strategic advantage. California Management Review, 57(1), 44-66.

Bingham, C. B., Furr, N. R., \& Eisenhardt, K. M. (2014). The opportunity paradox. MIT Sloan Management Review, 56(1), $29-35$.

Black, H. G., Vincent, L. H., \& Skinner, S. J. (2014). Customers helping customers: Payoffs for linking customers. Journal of Service Marketing, 28(5), 391-401.

Bogers, M., Afuah, A., \& Bastian, B. (2010). Users as innovators: A review, critique, and future research directions. Journal of Management, 36(4), 857-875.

Caru, A., \& Cova, B. (2003). Revisiting consumption experience: A more humble but complete view of the concept. Marketing Theory, 3(2), 267-286.

Chandler, J. D., \& Vargo, S. L. (2011). Contextualization and value-in-context: How context frames exchange. Marketing Theory, 11(1), 35-49.

Chesbrough, H. W. (2003). Open innovation: The new imperative for creating and profiting from technology. Boston, MA: Harvard Business School Publishing.

Christensen, C. M, \& Raynor, M. E. (2003). The innovator's solution: Creating and sustaining successful growth. Bosten, MA: Harvard Business School Press.

Edvardsson, B., Tronvoll, B., \& Gruber, T. (2011). Expanding understanding of service exchange and value co-creation: A social construction approach. Journal of the Academy of Marketing Science, 39(2), 327-339.

Enkel, E., Gassmann, O., \& Chesbrough, H. (2009). Open R\&D and open innovation: Exploring the phenomen. $R \& D$ Management, 39(4), 311-316.

Füller, J., Hutter, K., \& Faullant, R. (2011). Why co-creation experience matters? Creative experience and its impact on the quantity and quality of creative contributions. $R \& D$ Management, 41(3), 259-273.

Gallan, A. S., Jarvis, C. B., Brown, S. W., \& Bitner, M. J. (2013). Customer positivity and participation in services: An empirical test in a health care context. Journal of the Academy of Marketing Science, 41(3), 338-356. 
Galvagno, M., \& Dalli, D. (2014). Theory of value co-creation: A systematic literature review. Managing Service Quality: An International Journal, 24(6), 643-683.

Grönroos, C. (2000). Service management and marketing: A customer relationship management approach. West Sussex, UK: John Wiley \& Sons.

Grönroos, C. (2008). Service logic revisited: Who creates value? And who co-creates? European Business Review, 20(4), $298-314$

Grönroos, C. (2011). Value co-creation in a critical service logic: A critical analysis. Marketing Theory, 11(3), $279-301$.

Grönroos, C. (2012). Conceptualizing value co-creation: A journey to the 1970s and back to the future. Journal of Marketing Management, 28(13/14), 1520-1534.

Grönroos, C., \& Voima, P. (2013). Critical service logic: Marketing sense of value creation and co-creation. Journal of the Academy Marketing Science, 41, 133-150.

Gwinner, K. P., Bitner, M. J, Brown, S. W., \& Kumar, A. (2005). Service customization through employee adaptiveness. Journal of Service Research, 8(2), 131-148.

Hamel, G, \& Prahalad, C. K. (1994). Competing for the future. Boston, MA: Harvard Business School Press.

Holbrook, M. (2006). ROSEPEKICECIVECI versus CCV: The resource-operant, skill-exchanging, performanceexperiencing, knowledge-informed, competence-enacting, co-producer-involved, value-emerging, customer-interactive view of marketing versus the concept of customer value: "I can get it for you wholesale". In R. F. Lusch \& S. L. Vargo (Eds.), The service-dominant logic of marketing; dialog, debate and directions (208-223). Armonk, NY: M. E. Sharpe.

Hoveskog, M., Halila, F., \& Danilovic, M. (2015). Early phases of business model innovation: An ideation experience workshop in the classroom. Decision Sciences Journal of Innovative Education, 13(2), 177-195.

Hoyer, W. D., Chandy, R., Dorotic, M., Krafft, M., \& Singh, S. S. (2010). Consumer co-creation in new product development. Journal of Service Research, 13(3), 283-296.

Jaakola, E., and Hakanen, T. (2013). Value co-creation in solution networks. Industrial Marketing Management, 42(1), 4758.

Kotler, P., Armstrong, G., Harris, L. C., \& Piercy, N. (2013). Principles of marketing. Harlow, England: Pearson.

Leclercq, T., Hammedi, W., \& Poncin, I. (2016). Ten years of value cocreation: An integrative review. Recherche et Applications en Marketing, 31(3), 26-60.

Lewis, M. W., Andriopoulos, C., \& Smith, W. K. (2014). Paradoxical leadership to enable agility. California Management Review, 56(3), 58-77.

Lichtenthaler, U. (2009). Outbound open innovation and its effect on firm performance: Examining environmental influences. R\&D Management, 39(4), 317-330.

Mahr, D., Lievens, A., \& Blazevic, V. (2014). The value of customer co-created knowledge during the innovation process. Journal of Product Innovation Management, 31(3), 599-615.

Nambisan, S., \& Baron R. A. (2007). Interactions in virtual customer environments: Implications for products support and customer relationship management. Journal of Interactive Marketing, 21(2), 42-62.

Nätti, S., Pekkarinen, S., Hartikka, A., \& Holappa, T. (2014). The intermediator role in value co-creation within a triadic business service relationship. Industrial Marketing Management, 43(6), 977-984.

Neghina, C., Caniëls, M. C. J., Bloemer, J. M. M., \& Birgelen M. J. H. (2015). Value co-creation in service interactions: Dimensions and antecedents. Marketing Theory, 15(2), 221-242

Nordin, F., \& Kowalkowski, C. (2010). Solutions offerings: a critical review and reconceptualization. Journal of Service Management, 24(4), 441-459.

Ple, L., and Caceres, R. C. (2010). Not always co-creation: Introducing interactional co-destruction of value in servicedominant logic. Journal of Services Marketing, 24(6), 430-437.

Prahalad, C. K., \& Ramaswamy, V. (2004a). The future of competition: Co-creating unique value with customers. Strategy \& Leadership, 32(3), 4-9.

Prahalad, C. K., \& Ramaswamy, V. (2004b). Co-creation experiences: The next practice in value creation. Journal of Interactive Marketing, 18(3), 5-14.

Ramaswamy, V., \& Gouillart, F. (2010). The power of co-creation: Build it with them to boost growth, productivity, and profits. New York: Free Press.

Ramaswamy, V., \& Ozcan, K. (2014). The co-creation paradigm. Redwood City, CA: Stanford University Press.

Roberts, D., Hughes M., \& Kertbo, K. (2014). Exploring consumers' motivations to engage in innovation through co-creation activities. European Journal of Marketing, 48(1/2), 147-169. 
Roser, T., DeFilippi, R., and Samson, A. (2013). Managing your co-creation mix: Co-creation ventures in distinctive contexts. European Business Review, 25(1), 20-41.

Saarijärvi, H., Kannan, P.K., \& Kuusela, H. (2013). Value co-creation: Theoretical approaches and practical implications. European Business Review, 25(1), 6-19.

Sánchez-Fernández, R., \& Iniesta-Bonilla, A. M. (2007). The concept of perceived value: A systematic review of the research. Marketing Theory, 7(4), 427-451.

Santos-Vijande, M. L., González-Mieres. C., \& Lopez-Sanchez, J. A. (2013). An assessment of innovativeness in KIBS: Implications on KIBS' co-creation culture, innovation capability, and performance. Journal of Business \& Industrial Marketing, 28(2), 86-102.

Sawhney, M., Verona, G., \& Prandelli, E. (2005). Collaborating to create: The Internet as a platform for customer engagement in product innovation. Journal of Marketing, 73(5), 30-51.

Sebanz, N., Bekkering, H., \& Knoblich, G. (2006). Joint action: Bodies and minds moving together. Trends in Cognitive Science, 10(2), 70-76.

Sheth, J. N., \& Uslay, C. (2007). Implications of the revised definition of marketing: Form exchange to value creation. Journal of Public Policy \& Marketing, 26(2), 302-307.

Truong, Y., Simmons, G., \& Palmer, M. (2012). Reciprocal value propositions in practice: Constraints in digital markets. Industrial Marketing Management, 41(1), 197-206.

Ulwick, A. W. (2002). Turn customer input into innovation. Harvard Business Review, 80(1), 91-97.

Bettencourt, L. A., \& Ulwick, A. W. (2008). The customer-centered innovation map. Harvard Business Review, 86(5), 109114.

Vallaster, C., \& Von Wallpach, S. (2013). An online discursive inquiry into the social dynamics of multi-stakeholder brand meaning co-creation. Journal of Business Research, 66(9), 1505-1515.

Vargo, S. L., \& Lusch, R. F. (2004). Evolving to a new dominant logic for marketing. Journal of Marketing, 68(1), 1-17.

Vargo, S. L. (2008). Customer integration and value creation: Paradigmatic traps and perspectives. Journal of Service Research, 11(2), 211-215.

Vargo, S. L., \& Lusch, R. F. (2008). Service-dominant logic: Continuing the Evolution. Journal of the Academy of Marketing Science, 36(1), 1-10.

Vargo, S. L., \& Lusch, R. F. (2011). It's all B2B... and beyond: Toward a systems perspective of the market. Industrial Marketing Management, 40(2), 181-187.

Woodall, T. (2003). Conceptualising 'value for the customer': an attributional, structural and dispositional analysis. Academy of Marketing Science Review, 12(1), 1-42.

Xie, C., Bagozzi, R. P., \& Troye, S. V. (2008). Trying to presume: Toward a theory of consumers as a co-creators of value. Journal of the Academy of Marketing Science, 36(1), 109-122.

Zeithaml, V. A. (1988). Consumer perceptions of price, quality, and value: A means-end model and synthesis of evidence. The Journal of Marketing, 52(3), 2-22. 